\title{
Peptide nucleic acids (PNA) derived from \\ $N$-( $N$-methylaminoethyl)glycine. Synthesis, hybridization and structural properties§
}

\author{
Gerald Haaima, $\dagger^{a}$ Hanne Rasmussen, ${ }^{b}$ Günther Schmidt, ${ }^{a}$ Dorte K. Jensen, ${ }^{a}$ \\ Jette Sandholm Kastrup, ${ }^{b}$ Pernilla Wittung Stafshede, $\ddagger^{c}$ Bengt Nordén, ${ }^{c}$ \\ (the late) Ole Buchardt ${ }^{a}$ and Peter E. Nielsen*d \\ ${ }^{a}$ Center for Biomolecular Recognition, The H. C. Ørsted Institute, Universtitetsparken 5, \\ DK-2100 Ø, Copenhagen, Denmark \\ ${ }^{b}$ Department of Medicinal Chemistry, Royal Danish School of Pharmacy, Universtitetsparken 2, \\ DK-2100 Ø, Copenhagen, Denmark \\ ${ }^{c}$ Department of Physical Chemistry, Chalmers University of Technology, S-41296, Gothenburg, \\ Sweden \\ ${ }^{d}$ Center for Biomolecular Recognition, Department of Biochemistry and Genetics, Laboratory B, \\ The Panum Institute, Blegdamsvej 3c, DK-2200 N, Copenhagen, Denmark. \\ E-mail:pen@imbg.ku.dk
}

\section{Received (in Cambridge, UK) 15th March 1999, Accepted 24th May 1999}

Backbone $N$-methylated peptide nucleic acids (PNAs) containing the four nucleobases adenine, cytosine, guanine and thymine were synthesized via solid phase peptide oligomerization. The oligomers bind to their complementary target with a thermal stability that is $1.5-4.5^{\circ} \mathrm{C}$ lower per " $N$-methyl nucleobase unit" [dependent on the number and position(s) of the $N$-methyl] than that of unmodified PNA. However, even fully $N$-methyl modified PNAs bind as efficiently to DNA or RNA targets as DNA itself. Furthermore, the hybridization efficiency per $N$-methyl unit in a PNA decreased with increasing $N$-methyl content, and the effect was more pronounced when the $N$-methyl backbone units are present in the Hoogsteen versus the Watson-Crick strand in (PNA) $)_{2}$-DNA triplexes. Interestingly, $\mathrm{CD}$ spectral analyses indicate that $30 \%$ (3 out of ten) substitution with $N$-methyl nucleobases did not

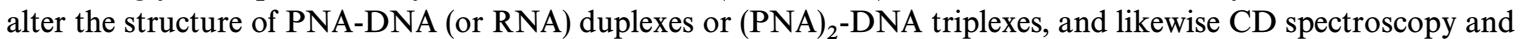
$\mathrm{X}$-ray crystallography showed no major structural differences between $N$-methylated $(30 \%)$ and unmodified PNA-PNA duplexes. However, PNA-DNA duplexes as well as triplexes adopted a different conformation when formed with all- $N$-methyl PNAs.

\section{Introduction}

Reagents that interact with DNA or RNA in a sequence specific manner are of great interest for the development of gene therapeutic drugs and diagnostic and molecular biology tools. ${ }^{1-3}$ Peptide nucleic acid (PNA) is a DNA mimic in which the sugar-phosphate backbone is replaced by a backbone consisting of $N$-(2-aminoethyl)glycine units. ${ }^{4-6}$ The chemical, biophysical and biological properties of PNA, not least the finding that PNA oligomers hybridize strongly and sequence specifically to complementary DNA, RNA or PNA oligomers, have attracted attention towards this and analogous peptide nucleic acids. ${ }^{7-12}$ A significant number of PNA derivatives with modifications in the backbone have been prepared and are currently being studied in order to understand the chemi-

$\dagger$ Present address: Center for Drug Design and Development, University of Queensland, Brisbane QLD 4072, Australia.

$\ddagger$ Present address: Beckman Institute, California Institute of Technology, Pasadena, 91125 California, USA.

§ Abbreviations used: DCC dicyclohexylcarbodiimide; DCU dicyclohexyl urea; DhbtOH 3,4-dihydo-3-hydroxy-4-oxo-1,2,3-benzotriazine; HATU $O$-(7-azabenzotriazol-1-yl)-1,1,3,3-tetramethyluronium hexafluorophosphate. cal and structural features which are important for nucleic acid binding and recognition as well as biological activity. $^{11-24}$

In order to further investigate the structure-activity relationships of PNA, a modified PNA backbone, which contains an $N$-(2-methylaminoethyl)glycine was considered. This substitution eliminates the hydrogen bonding donor capacity of the backbone as well as changes the hydrophilicity and hydration properties. It has been proposed on the basis of molecular modeling that the carbonyl of the linker to the nucleobase constitutes a potential hydrogen bonding acceptor for this amide proton, either in the direction of the amide $\mathrm{NH}$ of the same or to the preceeding nucleobase unit. ${ }^{25,26}$ However, neither $\mathrm{NMR}^{27,28}$ nor X-ray crystallographic ${ }^{29}$ three-dimensional structure determinations of PNA-DNA/ RNA/PNA duplexes or a (PNA) $)_{2}$-DNA triplex have supported such a hydrogen bonding pattern. In fact, the crystal structures show that the backbone amide protons of the Hoogsteen PNA strand in the (PNA) $)_{2}$-DNA triplex are involved in specific hydrogen bonds to the phosphates of the DNA backbone, ${ }^{29}$ whereas the backbone amide protons in the PNA-PNA duplex are hydrogen bonded to localized water molecules which bridge the nucleobase and the backbone. $^{30}$

In this paper we report the synthesis and hybridization 
analysis of PNA oligomers containing $N$-methylated glycine units at one or more positions along the backbone. Furthermore, the effect of backbone $N$-methylation on the structure of PNA complexes has been investigated by CD spectroscopy and X-ray crystallography.

\section{Experimental}

\section{General}

All reagents were obtained from commercial suppliers and used without further purification. Melting points are uncorrected. Flash chromatography was performed using Merck silica gel 60 (230-400 mesh ASTM). ${ }^{1} \mathrm{H}$ and ${ }^{13} \mathrm{C}$ NMR spectra were obtained in DMSO- $d_{6}$ using a Varian $400 \mathrm{MHz}$ Unity or a Bruker $250 \mathrm{MHz}$ AMX spectrometer. Fast atom bombardment mass spectra were recorded on a JEOL Hx110/110 operating in positive ion mode. MALDI-TOF mass spectra of PNA oligomers were recorded on a Kratos, Kompact Maldi II operating in positive ion mode and using 3,5-dimethoxy-4hydroxycinnamic acid as the matrix.

Analytical HPLC was carried out on a $3.9 \times 150 \mathrm{~mm}$ Delta Pak $5 \mu \mathrm{m}$ C-18 $100 \AA ̊$ column (Waters). Buffer A: 99.9\% $\mathrm{H}_{2} \mathrm{O}-0.1 \%$ TFA; Buffer B: $10 \% \mathrm{H}_{2} \mathrm{O}-89.9 \% \mathrm{CH}_{3} \mathrm{CN}-0.1 \%$ trifluoroacetic acid (TFA). The solvents were heated to $50^{\circ} \mathrm{C}$ while the flow rates were 1.0 for analytical and $2.0 \mathrm{ml} \mathrm{min}^{-1}$ for preparative HPLC.

RNA oligomers were purchased from DNA Technology, Aarhus, Denmark and were used as received, and DNA oligomers were synthesized by standard methods. Thermal denaturation studies $(\mathrm{Tm})$ were run on a Gilford Response II spectrophotometer scanning from 5 to $90^{\circ} \mathrm{C}$ at a rate of $0.5^{\circ} \mathrm{C}$ per step (approx. $0.7^{\circ} \mathrm{C} \mathrm{min}{ }^{-1}$ ). Prior to recording the $\mathrm{Tm}$, the complexes were heated to $95^{\circ} \mathrm{C}$ for $5 \mathrm{~min}$ and allowed to slowly cool to $4{ }^{\circ} \mathrm{C}$. The oligomers were hybridized in the following buffer: $100 \mathrm{mM} \mathrm{NaCl}-10 \mathrm{mM}$ sodium phosphate- 0.1 $\mathrm{mM} \mathrm{H}_{4}$ EDTA, $\mathrm{pH}$ 7.0. The concentrations of PNA and oligonucleotides were determined optically at $60^{\circ} \mathrm{C}$ using the molar absorptivities of the four nucleosides.

CD spectra were recorded on a Jasco model 720 spectropolarimeter equipped with a thermoelectrically controlled cell holder. Each spectrum is the average of at least eight scans, recorded at $20^{\circ} \mathrm{C}$ using $1 \mathrm{~cm}$ optical path length. The samples were kept in a $5 \mathrm{mM}$ sodium phosphate buffer at $\mathrm{pH}$ 7.0.

\section{Monomer synthesis}

$\boldsymbol{N}$-Methyl-1-aminopropane-2,3-diol 1. To a pre-cooled solution $\left(0^{\circ} \mathrm{C}\right)$ of methylamine $(172 \mathrm{ml}$ of a $40 \%$ solution in water, $2 \mathrm{~mol})$ was added 2,3-epoxypropan-1-ol (25 g, $0.34 \mathrm{~mol})$ at such a rate that the reaction temperature did not exceed $10^{\circ} \mathrm{C}$. After $3 \mathrm{~h}$ at $0^{\circ} \mathrm{C}$ excess methylamine and water were evaporated and the residue Kugelrohr distilled $\left(103-105^{\circ} \mathrm{C}, 0.5\right.$ $\mathrm{mmHg})$ resulting in $25.6 \mathrm{~g}(76 \%)$ of colorless oil. ${ }^{1} \mathrm{H}$ NMR $\left(400 \mathrm{MHz}, \mathrm{CDCl}_{3}\right): \delta 3.74(\mathrm{~m}, 1 \mathrm{H}, \mathrm{CH}), 3.56\left(\mathrm{~m}, 2 \mathrm{H}, \mathrm{CH}_{2}\right)$, $3.22\left(\mathrm{~m}, 2 \mathrm{H}, \mathrm{CH}_{2}\right), 2.94\left(\mathrm{~s}, 3 \mathrm{H}, \mathrm{NCH}_{3}\right)$; FAB-MS: $m / z 106$ $\left(\mathrm{M}^{+}+\mathrm{H}\right)$.

1-[ $N$-(tert-Butyloxycarbonyl)- $N$-methyl] aminopropane-2,3diol 2. Di-tert-butyl dicarbonate $(52.3 \mathrm{~g}, 0.24 \mathrm{~mol})$ was added to a pre-cooled $\left(0^{\circ} \mathrm{C}\right)$ solution of $1(21 \mathrm{~g}, 0.20 \mathrm{~mol})$ in water $(340 \mathrm{ml})$ and the mixture was allowed to warm to room temperature. The $\mathrm{pH}$ was maintained at 10.5 by addition of $4 \mathrm{M}$ aqueous $\mathrm{NaOH}$. After addition of 2 equivalents of $\mathrm{NaOH}$ the reaction was left to stir for $15 \mathrm{~h}$. Upon cooling to $0{ }^{\circ} \mathrm{C}$ and adjusting the $\mathrm{pH}$ to 2.5 using $4 \mathrm{M}$ aqueous $\mathrm{HCl}$ the reaction mixture was extracted with EtOAc $(6 \times 100 \mathrm{ml})$. The combined organic fractions were washed with half-saturated aqueous $\mathrm{KHSO}_{4}(3 \times 150 \mathrm{ml})$ followed by brine $(1 \times 150 \mathrm{ml})$. The organic fraction was then dried $\left(\mathrm{MgSO}_{4}\right)$ and concentrated to an oil. Kugelrohr distillation $\left(110-112^{\circ} \mathrm{C}, 0.5\right.$
$\mathrm{mmHg}$ ) furnished $31.3 \mathrm{~g}(81 \%)$ of the desired product as a colorless oil. ${ }^{1} \mathrm{H}$ NMR $\left(400 \mathrm{MHz}, \mathrm{CDCl}_{3}\right): \delta 3.72(\mathrm{~m}, 1 \mathrm{H}$, $\mathrm{CH}), 3.55\left(\mathrm{~m}, 2 \mathrm{H}, \mathrm{CH}_{2}\right), 3.22\left(\mathrm{~m}, 2 \mathrm{H}, \mathrm{CH}_{2}\right), 2.90(\mathrm{~s}, 3 \mathrm{H}$, $\left.\mathrm{NCH}_{3}\right), 1.43$ (s, 9H, $t$-Bu); FAB-MS: $m / z 206\left(\mathrm{M}^{+}+\mathrm{H}\right)$.

$2-\{[N$-(tert-Butyloxycarbonyl)- $N$-methyl] amino\} acetaldehyde 3. To a solution of $2(20 \mathrm{~g}, 97 \mathrm{mmol})$ in water $(100 \mathrm{ml})$ stirring under $\mathrm{N}_{2}$ was added $\mathrm{KIO}_{4}(24.68 \mathrm{~g}, 108 \mathrm{mmol})$. After $2.5 \mathrm{~h}$ the reaction mixture was filtered and the filtrate extracted with $\mathrm{CHCl}_{3}(5 \times 50 \mathrm{ml})$. The $\mathrm{CHCl}_{3}$ layers were dried $\left(\mathrm{MgSO}_{4}\right)$ and concentrated to an oil. Kugelrohr distillation $\left(76-80^{\circ} \mathrm{C}, 0.5 \mathrm{mmHg}\right)$ provided $13.26 \mathrm{~g}(79 \%)$ of a colorless oil. ${ }^{1} \mathrm{H}$ NMR $\left(400 \mathrm{MHz}, \mathrm{CDCl}_{3}\right): \delta 8.54(\mathrm{~s}, 1 \mathrm{H}$, major, CHO), 8.51 (s, 1H, minor, $\mathrm{CHO}$ ), 4.01 (s, 2H, major, $\mathrm{CH}_{2}$ ), $3.93\left(\mathrm{~s}, 2 \mathrm{H}\right.$, minor, $\left.\mathrm{CH}_{2}\right), 2.95$ (s, 3H, major, $\left.\mathrm{NCH}_{3}\right), 2.93(\mathrm{~s}$, $3 \mathrm{H}$, minor, $\left.\mathrm{NCH}_{3}\right), 1.47$ (s, 9H, major, $\left.t-\mathrm{Bu}\right) ; 1.42(\mathrm{~s}, 9 \mathrm{H}$, minor, $t$-Bu); FAB-MS: $m / z 174\left(\mathrm{M}^{+}+\mathrm{H}\right)$.

Ethyl $N$-\{2-[( $N$-tert-butyloxycarbonyl)- $N$-methyl] aminoethyl\}glycinate 4. Ethyl glycinate hydrochloride $(8.10 \mathrm{~g}, 58$ mmol) dissolved in absolute EtOH $(100 \mathrm{ml})$ was added dropwise to a cooled $\left(0^{\circ} \mathrm{C}\right)$ solution of $3(10.0 \mathrm{~g}, 58 \mathrm{mmol})$ and $\mathrm{NaOAc}(9.32 \mathrm{~g}, 114 \mathrm{mmol})$ in absolute EtOH $(130 \mathrm{ml})$. After addition of $10 \% \mathrm{Pd}$ on carbon $(1.65 \mathrm{~g})$ the reaction was hydrogenated $(1 \mathrm{~atm})$ until one equivalent of $\mathrm{H}_{2}$ was absorbed. The reaction mixture was filtered and to the filtrate was added water $(80 \mathrm{ml})$. After adjusting the $\mathrm{pH}$ to 8 with $2 \mathrm{M}$ aqueous $\mathrm{NaOH}$ the mixture was extracted with $\mathrm{CH}_{2} \mathrm{Cl}_{2}$ $(5 \times 60 \mathrm{ml})$. The organic layers were dried $\left(\mathrm{MgSO}_{4}\right)$ and concentrated to an oil. Kugelrohr distillation $\left(100-105^{\circ} \mathrm{C}, 0.5\right.$ $\mathrm{mmHg}$ ) furnished $10.6 \mathrm{~g} \mathrm{(74.3 \% )}$ of a colorless oil. ${ }^{1} \mathrm{H}$ NMR $\left(250 \mathrm{MHz}, \mathrm{CDCl}_{3}\right): \delta 4.18\left(\mathrm{q}, 2 \mathrm{H}, \mathrm{CH}_{2}\right), 3.42\left(\mathrm{~s}, 2 \mathrm{H}, \mathrm{CH}_{2}\right)$, $3.34\left(\mathrm{t}, 2 \mathrm{H}, \mathrm{CH}_{2}\right), 2.88\left(\mathrm{~s}, 3 \mathrm{H}, \mathrm{CH}_{3}\right), 2.77\left(\mathrm{t}, 2 \mathrm{H}, \mathrm{CH}_{2}\right), 1.45$ (s, $9 \mathrm{H}, t-\mathrm{Bu}), 1.28\left(\mathrm{t}, 3 \mathrm{H}, \mathrm{CH}_{3}\right)$; FAB-MS: $m / z 261\left(\mathrm{M}^{+}+\mathrm{H}\right)$.

General procedure for the synthesis of the monomer esters $5 \mathrm{a}-\mathrm{d}$

To a pre-cooled $\left(0^{\circ} \mathrm{C}\right)$ solution of $4(7.0 \mathrm{mmol})$, DhbtOH $(7.7$ $\mathrm{mmol}$ ) and the appropriate carboxymethyl derivative of the nucleobase $(7.7 \mathrm{mmol})$ in a $1: 1$ mixture of dry DMF- $\mathrm{CH}_{2} \mathrm{Cl}_{2}$ $(60 \mathrm{ml})$ was added DCC $(8.4 \mathrm{mmol})$. After stirring at $0{ }^{\circ} \mathrm{C}$ for 1 $\mathrm{h}$ followed by a further $3 \mathrm{~h}$ at room temperature the precipitated DCU was removed by filtration and the reaction work-up was as follows for each derivative.

Ethyl $N$-\{2-[(N-tert-butyloxycarbonyl)- $N$-methyl] aminoethyl $\}-N-[($ thymin-1-yl)acetyl] glycinate 5a. The reaction was diluted with $\mathrm{CH}_{2} \mathrm{Cl}_{2}(60 \mathrm{ml})$ and washed sequentially with half-saturated aqueous $\mathrm{NaHCO}_{3}(3 \times 30 \mathrm{ml})$, half-saturated aqueous $\mathrm{KHSO}_{4}(2 \times 30 \mathrm{ml})$ and brine $(1 \times 30 \mathrm{ml})$. The organic phase was dried $\left(\mathrm{MgSO}_{4}\right)$ and the solvent removed in vacuo. The resulting foam was redissolved in $\mathrm{CH}_{2} \mathrm{Cl}_{2}$, cooled to $0{ }^{\circ} \mathrm{C}$ and precipitated by slow addition of light petroleum (bp $40-60^{\circ} \mathrm{C}$ ) under vigorous stirring. The product was isolated as a white solid; $\mathrm{mp} 93-95^{\circ} \mathrm{C} ;{ }^{1} \mathrm{H}$ NMR $(400 \mathrm{MHz}$, $\left.\mathrm{CDCl}_{3}\right): \delta 11.20(\mathrm{~s}, 1 \mathrm{H}$, major, T-imid $\mathrm{NH}), 11.18(\mathrm{~s}, 1 \mathrm{H}$, minor, T-imid NH), 7.52 (s, 1H, major, T-H6), $7.50(\mathrm{~s}, 1 \mathrm{H}$, minor, T-H6), 4.60 (s, 2H, major, $\mathrm{CH}_{2} \mathrm{CON}$ ), 4.42 (s, $2 \mathrm{H}$, minor, $\mathrm{CH}_{2} \mathrm{CON}$ ), 4.32 (q, $\left.2 \mathrm{H}, \mathrm{OCH}_{2} \mathrm{CH}_{3}\right), 4.25$ (s, $2 \mathrm{H}$, minor, $\mathrm{CH}_{2} \mathrm{COOH}$ ), 4.07 (s, 2H, major, $\mathrm{CH}_{2} \mathrm{COOH}$ ), 3.60-3.10 (m, $\mathrm{CH}_{2} \mathrm{CH}_{2}$ ), 2.90 (s, $3 \mathrm{H}$, major, $\mathrm{BocNCH}_{3}$ ), 2.83 (s, 3H, minor, $\left.\mathrm{BocNCH}_{3}\right), 1.79\left(\mathrm{~s}, 3 \mathrm{H}, \mathrm{CH}_{3}\right), 1.39$ (s, 9H, t-Bu), 1.34 (t, 3H, $\left.\mathrm{OCH}_{2} \mathrm{CH}_{3}\right)$; FAB-MS: $m / z 427\left(\mathrm{M}^{+}+\mathrm{H}\right)$.

Ethyl $N$-\{2-[(N-tert-butyloxycarbonyl)- $N$-methyl] aminoethyl $\}-N-\{[4-N$-(benzyloxycarbonyl)cytosin-1-yl] acetyl $\}$ -

glycinate $\mathbf{5 b}$. The reaction mixture was evaporated to dryness and to the residue was added diethyl ether $(50 \mathrm{ml})$, this was stirred for $2 \mathrm{~h}$ and the solid filtered off. The solid was again stirred with $50 \mathrm{ml}$ ether for $2 \mathrm{~h}$ and filtered off, washing the solid with half-saturated aqueous $\mathrm{NaHCO}_{3}$. The solid was then dissolved in hot dioxane $(60 \mathrm{ml})$ and precipitated by slow addition of water $(60 \mathrm{ml})$. The product was further purified by 
column chromatography $\left(\mathrm{SiO}_{2}, \mathrm{MeOH}-\mathrm{CH}_{2} \mathrm{Cl}_{2}, 5: 95\right) ; \mathrm{mp}$ $152-156{ }^{\circ} \mathrm{C}$; ${ }^{1} \mathrm{H}$ NMR $\left(400 \mathrm{MHz}, \mathrm{CDCl}_{3}\right): \delta 7.98(\mathrm{~s}, 1 \mathrm{H}$, C-H5), 7.42-7.34 (m, 5H, Ph), 7.09 (s, 1H, C-H6), 5.19 (s, 2H, $\mathrm{PhCH}_{2}$ ), 4.85 (s, $2 \mathrm{H}$, major, $\left.\mathrm{CH}_{2} \mathrm{CON}\right), 4.62$ (s, $2 \mathrm{H}$, minor, $\mathrm{CH}_{2} \mathrm{CON}$ ), 4.28 (q, 2H, $\mathrm{OCH}_{2} \mathrm{CH}_{3}$ ), 4.17 (s, 2H, minor, $\mathrm{CH}_{2} \mathrm{COOH}$ ), 3.99 (s, 2H, major, $\mathrm{CH}_{2} \mathrm{COOH}$ ), 3.42-3.03 (m, $\mathrm{CH}_{2} \mathrm{CH}_{2}$ ), 2.97 (s, 3H, major, BocNCH$\left.{ }_{3}\right), 2.89$ (s, 3H, minor, $\left.\mathrm{BocNCH}_{3}\right), 1.39(\mathrm{~s}, 9 \mathrm{H}, t-\mathrm{Bu}), 1.24\left(\mathrm{t}, 3 \mathrm{H}, \mathrm{OCH}_{2} \mathrm{CH}_{3}\right)$; FAB-MS: $m / z 546\left(\mathrm{M}^{+}+\mathrm{H}\right)$.

Ethyl $N$-\{2-[(N-tert-butyloxycarbonyl)- $N$-methyl] aminoethyl $\}-N-\{[6-N$-(benzyloxycarbonyl)adenin-9-yl] acetyl $\}-$

glycinate 5c. The reaction mixture was evaporated to dryness, redissolved in $\mathrm{CH}_{2} \mathrm{Cl}_{2}(300 \mathrm{ml})$ and washed successively with half-saturated aqueous $\mathrm{NaHCO}_{3}(3 \times 100 \mathrm{ml})$, half-saturated aqueous $\mathrm{KHSO}_{4}(2 \times 100 \mathrm{ml})$ and brine $(1 \times 100 \mathrm{ml})$. The organic phase was dried $\left(\mathrm{MgSO}_{4}\right)$ and the solvent removed in vacuo. To the resulting foam in absolute $\mathrm{EtOH}(60 \mathrm{ml})$ was slowly added water $(30 \mathrm{ml})$. The mixture was left stirring overnight and the product was isolated by filtration; $\mathrm{mp} 140$ $143{ }^{\circ} \mathrm{C} ;{ }^{1} \mathrm{H}$ NMR $(400 \mathrm{MHz}, \mathrm{CDCl} 3): \delta 9.19$ (br s, $\left.1 \mathrm{H}, \mathrm{ZNH}\right)$, 8.74 (s, $1 \mathrm{H}$, major, $\mathrm{H}-8), 8.06$ (s, $1 \mathrm{H}$, minor, $\mathrm{H}-8), 7.47-7.32$ (m, $5 \mathrm{H}, \mathrm{Ph}), 5.29\left(\mathrm{~s}, 2 \mathrm{H}\right.$, major, $\left.\mathrm{CH}_{2} \mathrm{CON}\right), 5.14(\mathrm{~s}, 2 \mathrm{H}$, minor, $\left.\mathrm{CH}_{2} \mathrm{CON}\right), 5.24$ (s, 2H, $\left.\mathrm{PhCH}_{2}\right), 4.27$ (s, 2H, minor, $\mathrm{CH}_{2} \mathrm{COOH}$ ), 4.17 (q, 2H, $\mathrm{OCH}_{2} \mathrm{CH}_{3}$ ), 4.02 (s, 2H, major, $\mathrm{CH}_{2} \mathrm{COOH}$ ) ; 3.54-3.03 (m, $\mathrm{CH}_{2} \mathrm{CH}_{2}$ ), 2.93 (s, 3H, major, $\left.\mathrm{BocNCH}_{3}\right), 2.86\left(\mathrm{~s}, 3 \mathrm{H}\right.$, minor, BocNCH $\left.{ }_{3}\right), 1.40(\mathrm{~s}, 9 \mathrm{H}, t-\mathrm{Bu})$, $1.26\left(\mathrm{t}, 3 \mathrm{H}, \mathrm{OCH}_{2} \mathrm{CH}_{3}\right)$; FAB-MS: $m / z 570\left(\mathrm{M}^{+}+\mathrm{H}\right)$.

Ethyl $N$-\{2-[(N-tert-butyloxycarbonyl)- $N$-methyl] aminoethyl $\}-N-\{[6-N-$ (benzyloxycarbonyl)guanin-9-yl] acetyl $\}$ -

glycinate 5d. The reaction mixture was evaporated to dryness, redissolved in $\mathrm{CH}_{2} \mathrm{Cl}_{2}(80 \mathrm{ml})$ and washed with half-saturated aqueous $\mathrm{KHSO}_{4}(3 \times 40 \mathrm{ml})$. After drying $\left(\mathrm{MgSO}_{4}\right)$ and removal of the solvent in vacuo the desired product was isolated by crystallization from EtOAc; mp $157-159^{\circ} \mathrm{C} ;{ }^{1} \mathrm{H}$ NMR (400 MHz, $\mathrm{CDCl}_{3}$ ): $\delta 7.95(\mathrm{~s}, 1 \mathrm{H}$, major, G-H8), 7.88 (s, 1H, minor, G-H8), 7.55-738 (m, 5H, Ph), 5.37 (s, 2H, $\mathrm{PhCH}_{2}$ ), 5.18 (s, $2 \mathrm{H}$, major, $\mathrm{CH}_{2} \mathrm{CON}$ ), 5.00 (s, $2 \mathrm{H}$, minor, $\mathrm{CH}_{2} \mathrm{CON}$ ), 4.36 (s, $2 \mathrm{H}$, minor, $\left.\mathrm{CH}_{2} \mathrm{COOH}\right), 4.20\left(\mathrm{q}, 2 \mathrm{H}, \mathrm{OCH}_{2} \mathrm{CH}_{3}\right), 4.06$ (s, 2H, major, $\left.\mathrm{CH}_{2} \mathrm{COOH}\right), 3.62-3.32\left(\mathrm{~m}, \mathrm{CH}_{2} \mathrm{CH}_{2}\right), 2.94$ (s, $3 \mathrm{H}$, major, $\left.\mathrm{BocNCH}_{3}\right), 2.80$ (s, $3 \mathrm{H}$, minor, $\left.\mathrm{BocNCH}_{3}\right), 1.38$ (s, $9 \mathrm{H}, t-\mathrm{Bu}), 1.27\left(\mathrm{t}, 3 \mathrm{H}, \mathrm{OCH}_{2} \mathrm{CH}_{3}\right) ; \mathrm{FAB}-\mathrm{MS}: m / z 586$ $\left(\mathrm{M}^{+}+\mathrm{H}\right)$.

$N$ - $\{2-[(N$-tert-Butyloxycarbonyl)- $N$-methyl] aminoethyl $\}-N$ [(thymin-1-yl)acetyl] glycine 6a. To a solution of 5a (2.41 g, 5.6 $\mathrm{mmol})$ in $\mathrm{MeOH}(45 \mathrm{ml})$ at $0{ }^{\circ} \mathrm{C}$ was added $2 \mathrm{M} \mathrm{NaOH}(45$ $\mathrm{ml}$ ) and stirring was continued for $2 \mathrm{~h}$. The $\mathrm{pH}$ was adjusted to 2 with $2 \mathrm{M} \mathrm{HCl}$ and extracted with ethyl acetate. The organic phase was dried $\left(\mathrm{MgSO}_{4}\right)$ and evaporated to dryness yielding $1.45 \mathrm{~g}(52 \%)$ of a white solid; $\mathrm{mp} 119-122^{\circ} \mathrm{C} ;{ }^{1} \mathrm{H}$ NMR (400 MHz, DMSO- $\left.d_{6}\right): \delta 12.83(\mathrm{~s}, 1 \mathrm{H}, \mathrm{COOH}), 11.36$ (s, $1 \mathrm{H}$, major, T-imid $\mathrm{NH}$ ), 11.34 (s, $1 \mathrm{H}$, minor, T-imid $\mathrm{NH}$ ), 7.38 (s, 1H, major, T-H6), 7.34 (s, 1H, minor, T-H6), 4.72 (s, $2 \mathrm{H}$, major, $\mathrm{CH}_{2} \mathrm{CON}$ ), 4.54 (s, $2 \mathrm{H}$, minor, $\left.\mathrm{CH}_{2} \mathrm{CON}\right), 4.26(\mathrm{~s}$, $2 \mathrm{H}$, minor, $\left.\mathrm{CH}_{2} \mathrm{COOH}\right), 4.04\left(\mathrm{~s}, 2 \mathrm{H}\right.$, major, $\left.\mathrm{CH}_{2} \mathrm{COOH}\right)$, 3.70-3.10 (m, $\mathrm{CH}_{2} \mathrm{CH}_{2}$ ), 2.92 (s, 3H, major, $\left.\mathrm{BocNCH}_{3}\right), 2.84$ (s, $3 \mathrm{H}$, minor, $\left.\mathrm{BocNCH}_{3}\right), 1.75\left(\mathrm{~s}, 3 \mathrm{H}, \mathrm{CH}_{3}\right), 1.38(\mathrm{~s}, 9 \mathrm{H}, t-\mathrm{Bu})$; FAB-MS: $m / z 399\left(\mathrm{M}^{+}+\mathrm{H}\right)$; Calc. for $\mathrm{C}_{17} \mathrm{H}_{26} \mathrm{~N}_{4} \mathrm{O}_{7}: \mathrm{C}$, $51.25 ; \mathrm{H}, 6.58 ; \mathrm{N}, 14.07$. Found: $\mathrm{C}, 50.98 ; \mathrm{H}, 6.55 ; \mathrm{N}, 13.90 \%$.

$N-\{2-[(N-$ tert-Butyloxycarbonyl)- $N$-methyl] aminoethyl $\}-N$ $\{[4-N$-(benzyloxycarbonyl)cytosin-1-yl] acetyl\}glycine $6 \mathrm{~b}$. To a solution of $\mathbf{5 b}(1.17 \mathrm{~g}, 2.3 \mathrm{mmol})$ in THF $(40 \mathrm{ml})$ was added 1 $\mathrm{M}$ aqueous $\mathrm{LiOH}(60 \mathrm{ml})$. After $30 \mathrm{~min}$ the reaction was cooled to $0{ }^{\circ} \mathrm{C}$ and the $\mathrm{pH}$ was adjusted to 2 with $2 \mathrm{~N}$ aqueous $\mathrm{HCl}$. The mixture was extracted with $\mathrm{CH}_{2} \mathrm{Cl}_{2}$ and the organic phase was dried $\left(\mathrm{MgSO}_{4}\right)$ and evaporated yielding
$0.72 \mathrm{~g}(27 \%)$ of white foam; mp $181-184{ }^{\circ} \mathrm{C} ;{ }^{1} \mathrm{H}$ NMR $(400$ MHz, DMSO- $d_{6}$ ): $\delta 10.78$ (s, $\left.1 \mathrm{H}, \mathrm{COOH}\right), 7.88$ (s, 1H C-H5), 7.41-7.32 (m, 5H, Ph), 7.01 (s, 1H, C-H6), 5.19 (s, 2H, $\mathrm{PhCH}_{2}$ ), 4.81 (s, $2 \mathrm{H}$, major, $\mathrm{CH}_{2} \mathrm{CON}$ ), 4.62 (s, $2 \mathrm{H}$, minor, $\mathrm{CH}_{2} \mathrm{CON}$ ), 4.17 (s, 2H, minor, $\left.\mathrm{CH}_{2} \mathrm{COOH}\right), 3.98$ (s, 2H, major, $\mathrm{CH}_{2} \mathrm{COOH}$ ), 3.42-3.03 (m, $\mathrm{CH}_{2} \mathrm{CH}_{2}$ ), 2.94 (s, 3H, major, $\left.\mathrm{BocNCH}_{3}\right), 2.87\left(\mathrm{~s}, 3 \mathrm{H}\right.$, minor, BocNCH $\left.\mathrm{CH}_{3}\right), 1.38(\mathrm{~s}, 9 \mathrm{H}, t-\mathrm{Bu})$; FAB-MS: $m / z 518\left(\mathrm{M}^{+}+\mathrm{H}\right)$; Calc. for $\mathrm{C}_{24} \mathrm{H}_{31} \mathrm{~N}_{5} \mathrm{O}_{8}$ : C, $55.69 ; \mathrm{H}, 6.04 ; \mathrm{N}, 13.53$. Found: $\mathrm{C}, 55.35 ; \mathrm{H}, 5.99 ; \mathrm{N}, 13.28 \%$.

$N$ - $\{2-[(N$-tert-Butyloxycarbonyl)- $N$-methyl] aminoethyl $\}-N$ $\{[6-N$-(benzyloxycarbonyl)adenin-9-yl]acetyl\} glycine 6c. To a solution of $5 \mathrm{c}(3.14 \mathrm{~g}, 5.5 \mathrm{mmol})$ in $\mathrm{THF}$ at $0^{\circ} \mathrm{C}$ was added 1 $\mathrm{N}$ aqueous $\mathrm{LiOH}(25 \mathrm{ml})$. After $30 \mathrm{~min}$ the $\mathrm{pH}$ was adjusted to 1 with $2 \mathrm{~N}$ aqueous $\mathrm{HCl}$. The precipitate was filtered and dried yielding $1.62 \mathrm{~g}(57 \%)$ of a white solid; $\mathrm{mp} 171-173^{\circ} \mathrm{C}$; ${ }^{1} \mathrm{H}$ NMR (400 MHz, DMSO- $d_{6}$ ): $\delta 12.77$ (broad, $1 \mathrm{H}, \mathrm{COOH}$ ), 10.68 (broad, 1H, ZNH), 8.59 (s, 1H, major, A-H8), 8.35 (s, 1H, minor, A-H8), 7.48-7.32 (m, 5H, $\mathrm{Ph}), 5.37$ (s, 2H, major, $\mathrm{CH}_{2} \mathrm{CON}$ ), 5.18 (s, 2H, minor, $\mathrm{CH}_{2} \mathrm{CON}$ ), 5.23 (s, 2H, $\mathrm{PhCH}_{2}$ ), 4.35 (s, 2H, minor, $\mathrm{CH}_{2} \mathrm{COOH}$ ), 3.99 (s, 2H, major, $\mathrm{CH}_{2} \mathrm{COOH}$ ), 3.54-3.02 (m, $\mathrm{CH}_{2} \mathrm{CH}_{2}$ ), 2.93 (s, 3H, major, $\mathrm{BocNCH}_{3}$ ), 2.84 (s, 3H, minor, BocNCH $\mathrm{N}_{3}$ ), 1.39 (s, 9H, $t$-Bu); FAB-MS: $m / z 542\left(\mathrm{M}^{+}+\mathrm{H}\right)$; Calc. for $\mathrm{C}_{25} \mathrm{H}_{31} \mathrm{~N}_{7} \mathrm{O}_{7}$ : C, 55.44; H, 5.77; N, 18.10. Found: C, 55.10; H, 5.71; N, 17.81\%.

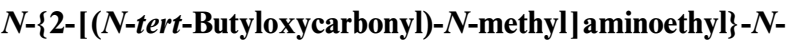
$\{[6-N$-(benzyloxycarbonyl)guanin-9-yl] acetyl\}glycine $6 \mathrm{~d}$. To a solution of $5 \mathbf{d}(2.33 \mathrm{~g}, 4.0 \mathrm{mmol})$ in $\mathrm{MeOH}(40 \mathrm{ml})$ was added $2 \mathrm{M}$ aqueous $\mathrm{NaOH}(40 \mathrm{ml})$. After $1 \mathrm{~h}$ at room temperature the reaction mixture was cooled to $0^{\circ} \mathrm{C}$ and the $\mathrm{pH}$ was adjusted to 2 using $2 \mathrm{M}$ aqueous $\mathrm{HCl}$. The precipitate was filtered, dried and recrystallised from absolute EtOH yielding $1.27 \mathrm{~g}(43 \%)$ of a white solid; mp $189-192{ }^{\circ} \mathrm{C} ;{ }^{1} \mathrm{H}$ NMR (400 $\left.\mathrm{MHz}, \mathrm{DMSO}-d_{6}\right): \delta 11.42$ (broad, $\left.1 \mathrm{H}, \mathrm{COOH}\right), 7.92(\mathrm{~s}, 1 \mathrm{H}$, major, G-H8), 7.85 (s, 1H, minor, G-H8), 7.55-738 (m, 5H, $\mathrm{Ph}$ ), 5.33 (s, $2 \mathrm{H}, \mathrm{PhCH}_{2}$ ), 5.18 (s, $2 \mathrm{H}$, major, $\mathrm{CH}_{2} \mathrm{CON}$ ), 5.00 (s, 2H, minor, $\left.\mathrm{CH}_{2} \mathrm{CON}\right), 4.32\left(\mathrm{~s}, 2 \mathrm{H}\right.$, minor, $\left.\mathrm{CH}_{2} \mathrm{COOH}\right)$, 4.05 (s, $2 \mathrm{H}$, major, $\left.\mathrm{CH}_{2} \mathrm{COOH}\right), 3.62-3.30\left(\mathrm{~m}, \mathrm{CH}_{2} \mathrm{CH}_{2}\right), 2.95$ (s, $3 \mathrm{H}$, major, BocNCH $\left.\mathrm{N}_{3}\right), 2.82$ (s, 3H, minor, $\left.\mathrm{BocNCH}_{3}\right), 1.38$ (s, 9H, $t$-Bu); FAB-MS: $m / z 558\left(\mathrm{M}^{+}+\mathrm{H}\right)$; Calc. for $\mathrm{C}_{25} \mathrm{H}_{31} \mathrm{~N}_{7} \mathrm{O}_{8}$ : C, 53.86; H, 5.60; N, 17.59. Found: C, 53.54; $\mathrm{H}, 5.54 ; \mathrm{N}, 17.30 \%$.

\section{Synthesis of PNA oligomers}

Coupling of the monomers was carried out according to published protocols ${ }^{31}$ using a 4-(methylbenzhydryl)amine resin down-loaded to $0.12 \mathrm{mmol} \mathrm{g}^{-1}$ with Boc-L-lysine(2-Cl$Z) \mathrm{OH}$. The PNAs were cleaved from the resin using a trifluoromethanesulfonic acid (TFMSA)-TFA procedure. ${ }^{31}$ Syntheses typically gave a crude product of greater than $90 \%$ purity as judged by reversed-phase HPLC. The oligomers were purified by HPLC and characterised by MALDI-TOF mass spectrometry.

\section{Crystallization of $\mathrm{H}-\mathrm{C}_{\mathrm{Me}} \mathrm{GT}_{\mathrm{Me}} \mathrm{AC}_{\mathrm{Me}} \mathrm{G}-(\mathrm{L}-\mathrm{Lys})-\mathrm{NH}_{2}$}

A $5 \mathrm{mg} \mathrm{ml}^{-1}$ solution of self-complementary $N$-methylated PNA [H-C $\mathrm{Me}_{\mathrm{Me}} \mathrm{GT}_{\mathrm{Me}} \mathrm{AC}_{\mathrm{Me}} \mathrm{G}$-(L-Lys)- $\left.\mathrm{NH}_{2}\right]$ was screened for crystallization conditions using the sparse-matrix screen of Jancarik and $\mathrm{Kim}^{32}$ from Hampton Research. Optimization of initial crystallization conditions resulted in crystals of size $0.600 \times 0.250 \times 0.075 \mathrm{~mm}$. The hanging-drop vapor-diffusion method was used at room temperature with drop sizes of $5 \mu 1$ (3 $\mu \mathrm{l} \mathrm{N}$-methylated PNA solution and $2 \mu 1$ well solution) and $0.5 \mathrm{ml}$ of well solution. The well solution contained $0.4 \mathrm{M}$ $\mathrm{MgCl}_{2}, 5 \%$ ethanol, $0.075 \mathrm{M}$ TRIS $\cdot \mathrm{HCl} \mathrm{pH} \mathrm{7.2,} \mathrm{and} 3.0 \mathrm{M}$ hexane-1,6-diol. $N$-Methylated PNA crystallizes in space group $P 2_{1}$ with cell dimensions $a=48.94, \quad b=31.00$, $c=50.74 \AA$, $\beta=111.78^{\circ}$. 
Table 1 Diffraction data and refinement statistics

\begin{tabular}{|c|c|c|}
\hline \multicolumn{3}{|l|}{ Diffraction data } \\
\hline Resolution $/ \AA^{2}$ & $25.0-2.2$ & $(2.24-2.20)$ \\
\hline Unique reflections & 6794 & \\
\hline Completeness $(\%)$ & 92.0 & $(93.0)$ \\
\hline Multiplicity & 1.6 & \\
\hline$R_{\text {merge }}(I)^{a}(\%)$ & 7.5 & $(30.0)$ \\
\hline$I / \sigma I$ & 6.6 & $(2.2)$ \\
\hline \multicolumn{3}{|l|}{ Refinement } \\
\hline \multicolumn{3}{|l|}{ Resolution/A } \\
\hline \multicolumn{2}{|c|}{ Number of reflections } & 4049 \\
\hline$\sigma$ cut-off & & \\
\hline \multicolumn{2}{|c|}{$R$-value $/ R_{\text {free }}-$ value $^{b}(\%)$} & $21.4 / 29.4$ \\
\hline \multicolumn{2}{|c|}{ Total number of non-hydrogen atoms } & 1343 \\
\hline \multicolumn{2}{|c|}{ Water molecules } & 207 \\
\hline \multicolumn{2}{|c|}{ Average $B$-values of PNA units $/ \AA^{2}$} & 19 \\
\hline \multicolumn{2}{|c|}{ Average $B$-values of L-Lys units $/ \AA^{2}$} & 51 \\
\hline \multirow{2}{*}{\multicolumn{2}{|c|}{ Average $B$-values of water molecules $/ \AA^{2}$}} & 41 \\
\hline & & 0.015 \\
\hline \multicolumn{2}{|c|}{ R.m.s. deviation of bond angles/ ${ }^{\circ}$} & 3.7 \\
\hline \multicolumn{3}{|c|}{$\begin{array}{l}R_{\text {merge }}=\text { agreement between symmetry related reflections. }{ }^{b} R_{\text {free }}= \\
\text { cross-validation } R \text {-value for test set of reflections }(10 \%) \text { omittec } \\
\text { during the refinements. }\end{array}$} \\
\hline
\end{tabular}

\section{Crystallography}

Data collection. A diffraction data set of $N$-methylated PNA was collected to $2.2 \AA$ resolution using one crystal on a Rigaku RU-200 rotating-anode generator equipped with an R-AXIS II imaging plate detector $(\lambda=1.542 \AA, 50 \mathrm{kV}, 180$ $\mathrm{mA}$, normal focus). The data collection was performed at room temperature with a crystal-detector distance of $100 \mathrm{~mm}$ and with $180^{\circ}$ rotation in steps of $3^{\circ}$ oscillations. Autoindexing and data processing were performed with $\mathrm{DENZO}^{33}$ and the CCP4 suite of programs. ${ }^{34}$ The statistics of the data set are tabulated in Table 1.

Structure determination and refinement. The structure of $\mathrm{N}$ methylated PNA was solved by molecular replacement using the program $\mathrm{AMoRe}^{35}$ from CCP4. Two right-handed and two left-handed double helices have been located per asymmetric unit. The two right-handed and the two left-handed helices, respectively, are related by a translation of $0.50,0.50$, 0.15 , as indicated in a native Patterson map. Initially, a righthanded double helix, coaxially stacked with a left-handed helix, of an unmodified PNA-PNA hexamer was used as search model $^{30}$ in the resolution range 10.0-3.0 $\AA$. One clear solution to the translation function appeared with the best solution from the rotation search. A second translation search was conducted, fixing the first solution to the translation function. After each translational search, ten cycles of rigid-body refinement were performed using AMoRe, resulting in $R$ factors of $56.3 \%$ and $52.7 \%$, respectively, and correlation coefficients of 64.4 and 72.3 .

The four double helices were subjected to a positional refinement protocol in X-PLOR ${ }^{36}$ using data in the resolution range $6.0-2.2 \AA$ and a $3 \sigma$ cut-off, alternating with graphical sessions using the program O. ${ }^{37}$ Non-crysytallographic symmetry restrains were applied during refinement. $B$-Factor refinement and water molecules were included in the early cycles of refinement. The final $R$-value was $21.4 \%$ and the final refinement statistics and average $B$-values are tabulated in Table 1. The atomic coordinates of $N$-methylated PNA have been deposited in the Brookhaven Protein Data Bank, accession code RCSB009127.

\section{Results and discussion}

\section{Synthesis of $N$-methyl monomers and oligomerization}

Monomers suitable for incorporation using Boc-based peptide synthesis were prepared according to Scheme 1. Essentially the chemistry was adapted from existing chemistry used to

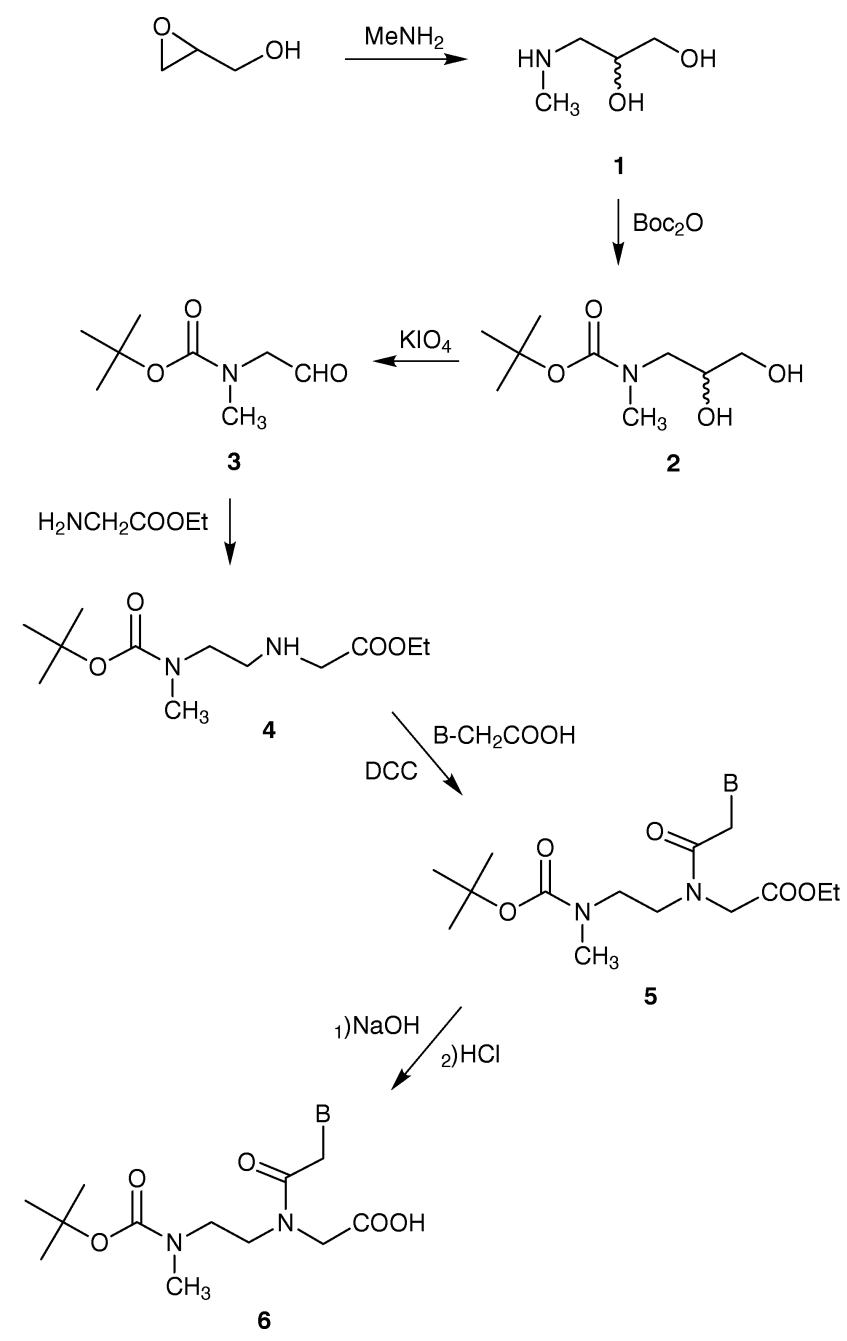

Scheme 1 B $=$ a thymine, b $N^{4}$-benzyloxycarbonylcytosine, c $N^{6}$ benzyloxycarbonyladenine, d $N^{2}$-benzyloxycarbonylguanine.

construct the regular PNA monomers. ${ }^{31,38,39}$ Reaction of aqueous methylamine with 2,3-epoxypropanol produced 1 which after Boc protection of the amine was oxidatively cleaved with $\mathrm{KIO}_{4}$ to produce 3 . The backbone 4 was obtained from reductive alkylation of ethyl glycinate with $\mathbf{3}$. The nucleobase acetic acids were synthesised as described in the literature. ${ }^{38}$ Coupling of the four nucleobase acetic acids using DCC-DhbtOH followed by alkaline hydrolysis yielded the four monomers $\mathbf{6 a}-\mathbf{d}$.

\section{Duplex formation and stability}

Decamer PNA oligomers of mixed pyrimidine-purine content were used for studies of duplex formation with complementary DNA, RNA and PNA oligomers. Two PNAs were synthesised; PNA I containing three $N$-methyl backbone thymines and PNA II in which all monomers derived from the $N$ methyl backbone. Thermal stability studies of the duplexes formed between these PNAs and DNA, RNA or PNA are presented in Table 2 . The data clearly demonstrate that inclusion of $N$-methyl backbone units results in a decrease in thermal stability of the PNA-nucleic acid duplexes of $1-3{ }^{\circ} \mathrm{C}$ per $N$ methyl unit. It is also observed that the effect is less pronounced for RNA (and PNA) binding and that the effect of having more $N$-methyl units is not "additive", since the cost per $N$-methyl is higher for PNA I than for PNA II. Furthermore, we note that even the fully methylated PNA II exhibits PNA-nucleic acid duplex stabilities that are equal to (DNA) or significantly higher (RNA) than that of the corresponding DNA oligonucleotide. Finally, it is interesting that the relative 
Table 2 Thermal stabilities $\left(\mathrm{Tm} /{ }^{\circ} \mathrm{C}\right)$ of PNA-DNA, PNA-RNA, PNA-PNA duplexes

\begin{tabular}{|c|c|c|c|c|c|c|}
\hline PNA-DNA & $\begin{array}{l}\text { Anti-parallel DNA } \\
\text { duplex }^{a}\end{array}$ & $\begin{array}{l}\text { Parallel DNA } \\
\text { duplex }^{b}\end{array}$ & Mismatch $^{c}$ & $\mathrm{RNA}^{d}$ & RNA mismatch ${ }^{e}$ & PNA $^{f}$ \\
\hline $\mathrm{H}-\mathrm{GT}_{\mathrm{Me}} \mathrm{AGAT}_{\mathrm{Me}} \mathrm{CACT}_{\mathrm{Me}}-\mathrm{NH}_{2}(\mathrm{I})$ & $41.5(2.8)^{g}$ & 37.5 & $\sim 37^{h}$ & $48.5(1.8)$ & 39 & $63.0(1.3)$ \\
\hline $\mathrm{H}-(\mathrm{GTAGATCACT})_{\mathrm{Me}}-\mathrm{LysNH}_{2}$ (II) & $33.0(1.8)$ & 34.5 & - & $44.0(1.2)$ & - & $61.5(0.6)$ \\
\hline H-GTAGATCACT-NH ${ }_{2}$ (IIIa) & 50 & 38.5 & $\sim 40^{h}$ & 54 & 44 & 67 \\
\hline H-GTAGATCACT-LysNH ${ }_{2}$ (IIIb) & 51 & 38 & $\sim 37^{h}$ & 56 & 46 & 67 \\
\hline 5'-GTAGATCACT-3' & 33.5 & & 26.5 & 34 & 32 & 49 \\
\hline
\end{tabular}

${ }^{a} 5^{\prime} \mathrm{d}$ (AGTGATCTAC). ${ }^{b} 5^{\prime} \mathrm{d}$ (CATCTAGTGA). ${ }^{c} 5^{\prime} \mathrm{d}$ (AGTGGTCTAC). ${ }^{d} 5^{\prime}$ (AGUGAUCUAC). ${ }^{e} 5^{\prime}$ (AGUGGUCUAC). ${ }^{f}$ H-AGTGATCTAC$\mathrm{LysNH}_{2} \cdot{ }^{g} \Delta \mathrm{Tm}$ per $N$-methyl unit given in parentheses. ${ }^{h}$ Due to a thermal transition of the single stranded PNA itself around $40{ }^{\circ} \mathrm{C}$, this value is difficult to determine accurately.

Table 3 Thermal stabilities $\left(\mathrm{Tm} /{ }^{\circ} \mathrm{C}\right)$ of $\left(\mathrm{PNA}_{2}\right)$-DNA triplexes

\begin{tabular}{|c|c|c|c|c|}
\hline PNA & DNA $(\mathrm{ap})^{a}$ & DNA $(p)^{b}$ & $\mathrm{RNA}^{c}$ & $\mathrm{PNA}^{c}$ \\
\hline $\mathrm{H}_{-} \mathrm{T}_{10}-\mathrm{LysNH}_{2}(\mathbf{I V})$ & $71.5(0)^{d}$ & & 81 & 70 \\
\hline H-TTTTTT $_{\mathrm{Me}}$ TTTT-LysNH ${ }_{2}(\mathbf{V})$ & $66.0(2.7)$ & & & 56 \\
\hline 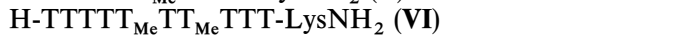 & $61.5(2.5)$ & & & 63.5 \\
\hline $\mathrm{H}^{-T T T T} \mathrm{Me}_{\mathrm{Me}} \mathrm{TT}_{\mathrm{Me}} \mathrm{TT}^{\mathrm{Me}} \mathrm{LysNH}_{2}$ (VII) & $57.0(1.5)$ & & 58 & 56.5 \\
\hline H-Gly-(TTTTTTTTTT) $)_{\mathrm{Me}}-\mathrm{LysNH}_{2}$ (VIII) & $43.0(1.4)$ & & 42 & 48 \\
\hline H-TJTJTTT(eg) ${ }_{3}$-TTTCTCT-LysNH 2 (IX) & $64.0(0)$ & 49 & & \\
\hline $\mathrm{H}-\mathrm{T}_{\mathrm{Me}} \mathrm{JT}_{\mathrm{Me}} \mathrm{JT}_{\mathrm{Me}} \mathrm{T}_{\mathrm{Me}} \mathrm{T}_{\mathrm{Me}}(\mathrm{eg})_{3} \mathrm{TTTCTCT} \mathrm{LysNH}_{2}(\mathbf{X})$ & $42.0(4.4)$ & $\approx 39$ & & \\
\hline H-TJTJTTT(eg) ${ }_{3} \mathrm{~T}_{\mathrm{Me}} \mathrm{T}_{\mathrm{Me}} \mathrm{T}_{\mathrm{Me}} \mathrm{C}_{\mathrm{Me}} \mathrm{T}_{\mathrm{Me}} \mathrm{C}_{\mathrm{Me}} \mathrm{T}_{\mathrm{Me}}-\mathrm{LysNH}_{2}$ (XI) & $40.5(3.3)$ & 31 & & \\
\hline TJTJTTT(eg) ${ }_{3} \mathrm{~T}_{\mathrm{Me}} \mathrm{T}_{\mathrm{Me}} \mathrm{T}_{\mathrm{Me}} \mathrm{CT}_{\mathrm{Me}} \mathrm{CT}_{\mathrm{Me}}-\mathrm{LysNH}_{2}$ (XII) & $48.5(2.2)$ & 32.5 & & \\
\hline TJTJTTT(eg) ${ }_{3}$ TTTC $_{\mathrm{Me}}$ TC $_{\mathrm{Me}}$ T-LysNH $_{2}$ (XIII) & $55.5(4.3)$ & 32 & & \\
\hline
\end{tabular}

preference of PNA for binding to DNA in the antiparallel orientation is diminished (PNA I) or completely abolished (PNA II) for the $N$-methylated PNAs.

\section{Triplex formation and stability}

Two formats were chosen for the study of (PNA) $)_{2}$-DNA triplexes. The first consisted of a $T_{10}$ with an increasing number $(1,2,3$ or 10$)$ of $N$-methyl substitutions. The second format was a bis(PNA) in which the $N$-methyl substitutions were made in the Watson-Crick or the Hoogsteen strand, respectively. The results are presented in Table 3. Analogously to what was observed for duplex formation, inclusion of the $\mathrm{N}$ methylated PNA backbone decreases the thermal stability of the (PNA) $)_{2}$-DNA triplexes by an average $2{ }^{\circ} \mathrm{C}$ per $N$-methyl unit, and the effect is diminished with an increasing number of $N$-methyl units (compare PNAs V-VIII). [Using PNA VII as a representative case, we performed a titration (Job-plot) to ascertain that indeed (PNA) $)_{2}$-DNA triplexes are formed by these $N$-methyl substituted PNAs (Fig. 1)]. In order to address whether the effect of the methylation was confined to

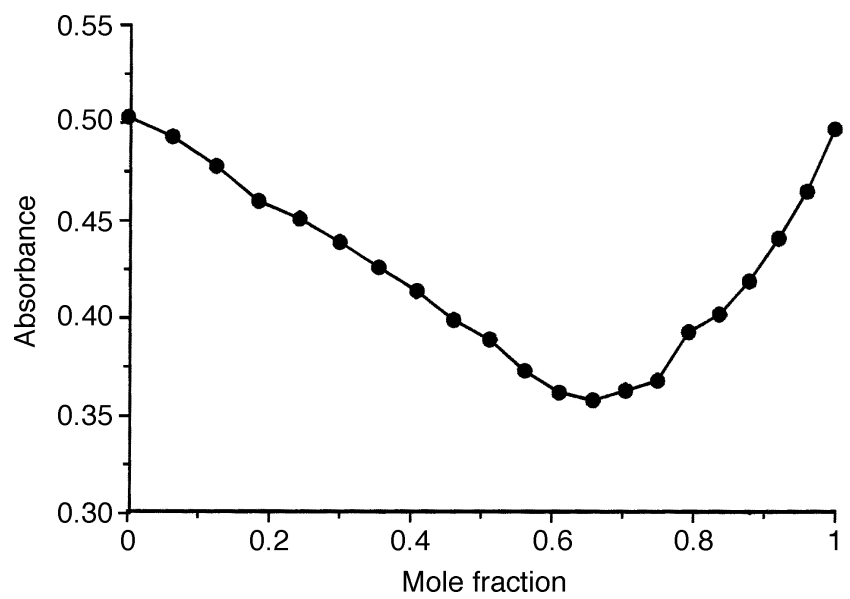

Fig. 1 Titration (Job-plot) of the binding of PNA VII to a complementary oligonucleotide $\left(\mathrm{dA}_{10}\right)$. the Watson-Crick interaction or was also affecting the Hoogsteen strand, we synthesized a series of linked bis(PNAs) in which the preferred binding mode (Watson-Crick versus Hoogsteen) can be controlled by the orientation of the PNA strands (antiparallel orientation is preferred by the WatsonCrick PNA strand whereas parallel orientation is preferred by the Hoogsteen PNA strand), as well as the position of pseudoisocytosine $(\mathrm{J})$ nucleobases, which do not require low $\mathrm{pH}$ for optimal J-G Hoogsteen type interactions. ${ }^{40}$ Thus for the triplexes of PNAs IX-XIII presented in Table 3, Hoogsteen binding should be preferred by the "J-strand", while WatsonCrick binding should take place with the "C-strand". This assignment is supported by the fact that all of these PNAs bind more strongly to the DNA complement that is antiparallel to the PNA "C-strand" than to the DNA complement that is parallel to this strand (Table 3). Therefore by comparing the result obtained with PNA $\mathbf{X}$ having five (thymine) $N$-methyl units in the Hoogsteen strand $\left(\Delta \mathrm{Tm}=4.4^{\circ} \mathrm{C}\right)$ with that of PNA XII having five (thymine) $N$-methyl units in the Watson-Crick strand $\left(\Delta \mathrm{Tm}=2.2^{\circ} \mathrm{C}\right)$ we conclude that $N$-methylation affects the stability of both strands, and that the interference seems greater in the Hoogsteen strand.

\section{CD spectroscopy}

We applied circular dichroism spectroscopy to monitor any effects of the backbone $N$-methylation on the structure of the PNA-nucleic acid complexes. The results presented in Fig. 2 and 3 clearly show that no major structural change occurs in the PNA-DNA or PNA-RNA duplexes or (PNA) $)_{2}$-DNA triplexes upon introduction of $30 \%$ (three out of ten) $N$-methyl units in the PNA strand(s). However, most interestingly, the complexes (duplex or triplex) formed by the fully methylated PNAs II and VIII show distinctly altered CD spectra, strongly suggesting that these complexes also have structures that distinguish them from those formed by the normal PNAs. On the other hand no major difference between the PNA-PNA duplexes formed by the fully methylated PNA II as compared to that of the normal PNA I was apparent from CD spectroscopy (Fig. 4). 


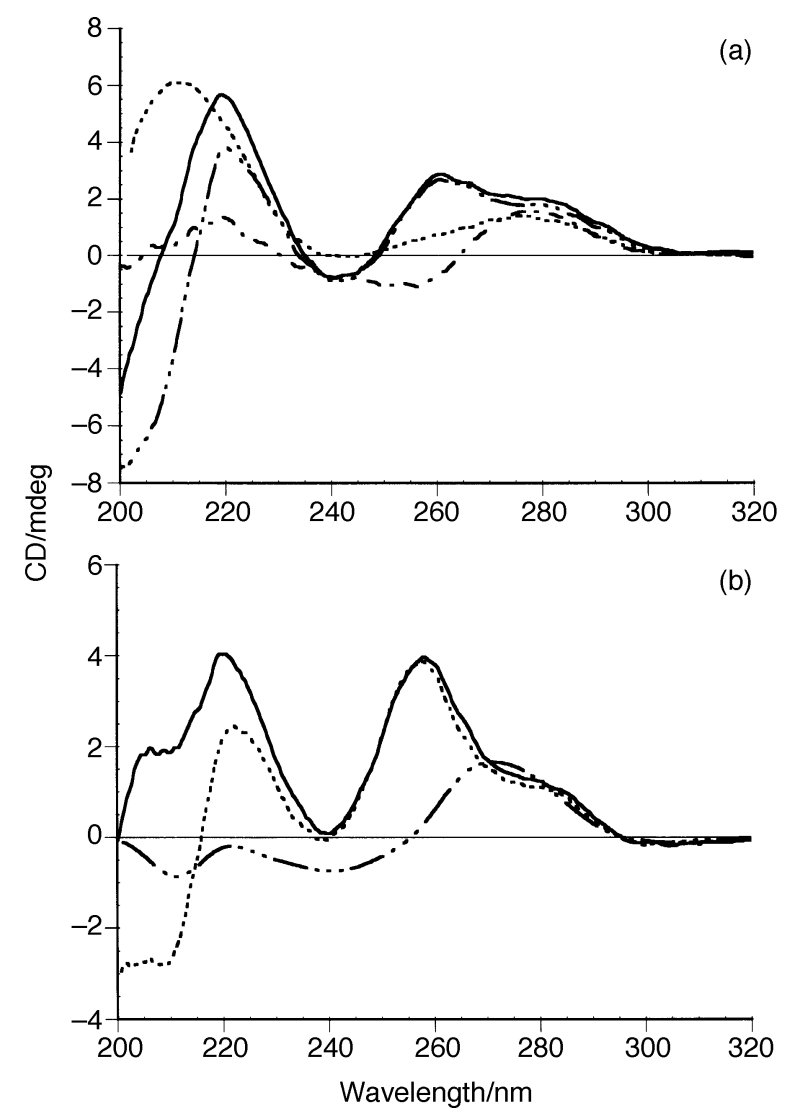

Fig. 2 Circular dichroism (CD) spectra of the duplexes between PNAs I (-), II (----) or the control PNA IIIa $(-\cdots-)$ and the antiparallel DNA (a) or RNA (b) oligonucleotide (5'-AGTGATCTAC) . CD spectra of the free DNA or RNA are shown by (-. - ).

This is also consistent with the observation that $N$-methyl backbone substitutions are more easily accommodated in PNA-PNA duplexes $\left(\Delta \mathrm{Tm} \approx 0.6-1.3^{\circ} \mathrm{C}\right.$ per $N$-methyl substitution) than in PNA-DNA (RNA) duplexes $(\Delta \mathrm{Tm} 1.2-$ $2.8^{\circ} \mathrm{C}$ per substitution). It has been shown that a PNA-PNA duplex adopts a novel helical conformation, the P-form ${ }^{30}$ that shows a much larger helical pitch $(\approx 18$ bases per turn) and diameter $(\approx 28 \AA)$ than the natural B- or A-form conformations which are closer to the structures adopted by PNA-DNA and PNA-RNA duplexes. ${ }^{27,28}$ Thus it appears that the $N$-methyl PNA backbone can be quite easily accommodated in the P-type helix, whereas it is more difficult in the B- or A-type helices.

The (PNA) $)_{2}$-DNA triplexes also adopt a P-type conformation, ${ }^{29}$ but nonetheless do not seem to accommodate the $\mathrm{N}$ -

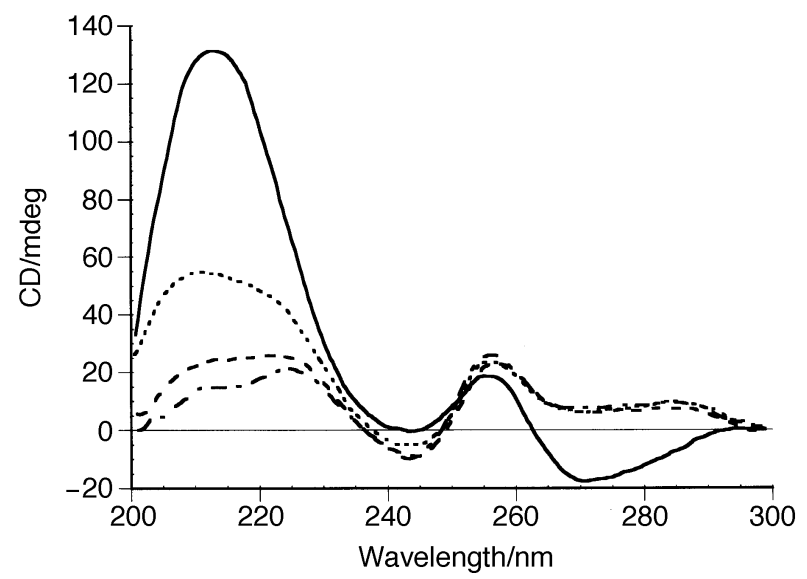

Fig. $3 \mathrm{CD}$ spectra of the triplexes between $\mathrm{dA}_{10}$ and $T_{10}$ PNAs IV (control) (-.-), $\mathbf{V}$ (one $N$-methyl) $(----)$, VII (three $N$-methyl) $(----)$, and VIII (full $N$-methyl) (

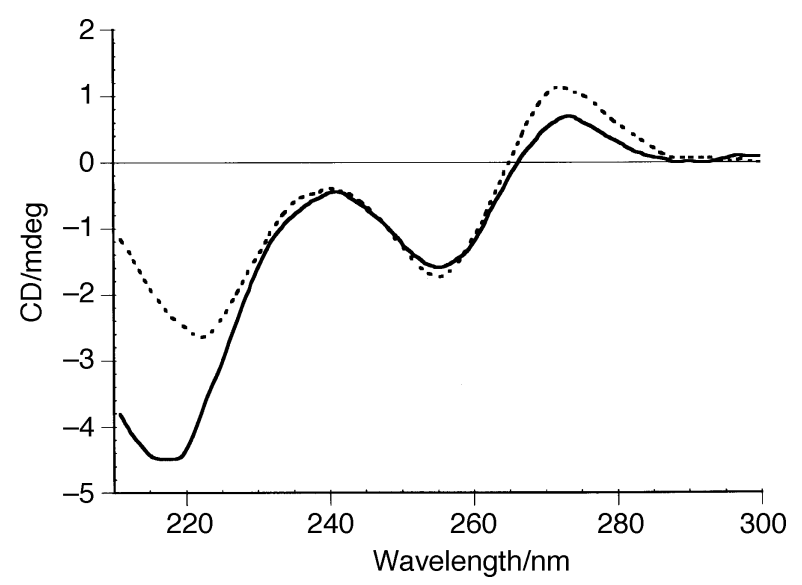

Fig. 4 CD spectra of the duplexes formed between PNA II ( - ) or the control PNA I (-----) and a complementary PNA (having a C-terminal L-lysine).

methyl backbone any better than PNA-DNA (RNA) duplexes. Furthermore, the largest effect is seen when the $N$-methyl backbone is placed in the Hoogsteen strand (compare PNAs $\mathbf{X}$ and XIII). This is most likely due to disruption of $\mathrm{N}$ $\mathrm{H}$ - . phosphate hydrogen bonding interactions between the backbone of the DNA and the Hoogsteen PNA strand as observed in the crystal structure and suggested to provide extra stabilization of the (PNA) $)_{2}$-DNA triplex. ${ }^{29}$

\section{Crystal structure determination}

The structure of a $50 \% N$-methylated PNA hexamer $[\mathrm{H}-$ $\mathrm{C}_{\mathrm{Me}} \mathrm{GT}_{\mathrm{Me}} \mathrm{AC}_{\mathrm{Me}} \mathrm{G}$-(L-Lys)- $\mathrm{NH}_{2}$ ] was determined in order to establish how the $N$-methyl backbone is accommodated in the P-type helix of PNA-PNA duplexes. The asymmetric unit of the crystal contains two pairs of coaxially stacked righthanded and left-handed double helices (Fig. 5). As previously observed, ${ }^{30}$ this results, by crystallographic symmetry, in the formation of a continuous pseudo-helix, alternating between right- and left-handed forms. The two right-handed and the two left-handed helices are very similar. The $N$-methylated PNA hexamer adopts the P-form helix (Table 4) with helical parameters close to those of the unmodified PNA-PNA duplex. ${ }^{30}$
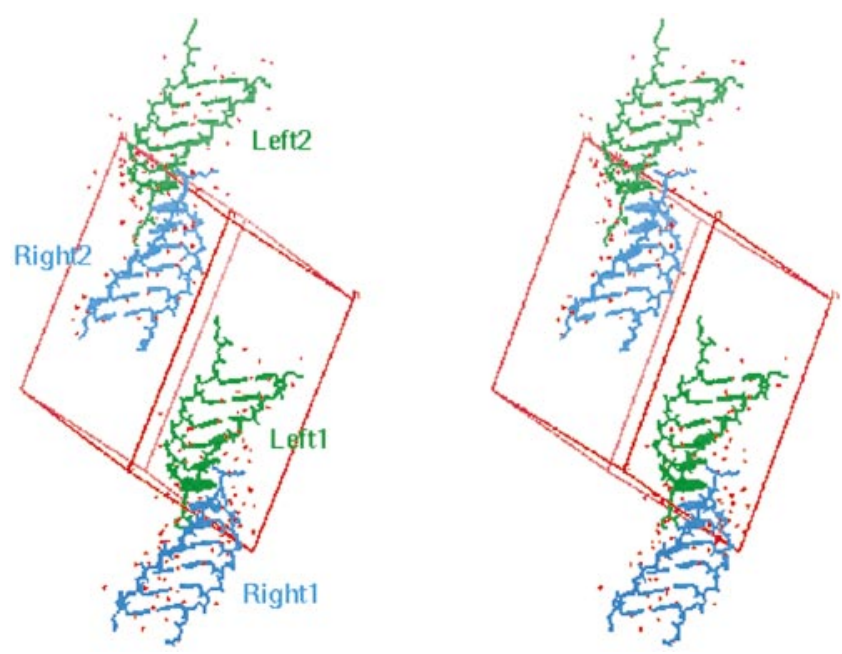

Fig. 5 The $N$-methylated PNA hexamer crystallizes with two righthanded (cyan) and two left-handed (green) double helices in the asymmetric unit. The right-handed and left-handed helices are coaxially stacked. The two right-handed and the two left-handed helices, respectively, are related by non-crystallographic translational symmetry. The unit cell with axes is shown in stereo. The figure was generated using the program $\mathrm{O}^{37}$ 
Table 4 Helical parameters (average) ${ }^{a}$ of the $N$-methylated PNA-PNA duplex

\begin{tabular}{|c|c|c|c|c|c|}
\hline & Twist (\%) & Rise $/ \AA$ & Base tilt (\%) & Displacement/Å & Bases per turn \\
\hline \multicolumn{6}{|l|}{$\mathrm{N}-\mathrm{Me} \mathrm{PNA}^{b}$} \\
\hline Right1 & 18.9 & 3.8 & 0.2 & 4.8 & 18 \\
\hline Right2 & 19 & 3.8 & 0.1 & 4.9 & 18 \\
\hline Left 1 & -20 & 3.5 & 0 & 7.2 & 18 \\
\hline Left 2 & -20 & 3.5 & 0.3 & 7.2 & 18 \\
\hline Unmodified $\mathrm{PNA}^{c}$ & 19.8 & 3.2 & 1 & 8.3 & 18 \\
\hline
\end{tabular}

${ }^{a}$ The helical parameters were determined using the program CURVES. ${ }^{41}{ }^{b} \mathrm{~N}-\mathrm{Me}$ PNA: backbone $N$-methylated PNA-PNA duplex $[\mathrm{H}-$ $\mathrm{C}_{\mathrm{Me}} \mathrm{GT}_{\mathrm{Me}} \mathrm{AC}_{\mathrm{Me}} \mathrm{G}-(\mathrm{L}-\mathrm{Lys})-\mathrm{NH}_{2}$ ]. ${ }^{c}$ Unmodified PNA: unmodified PNA-PNA duplex (H-CGTACG-NH $\left.{ }_{2}\right) .{ }^{30}$

The major structural difference between $N$-methylated and unmodified PNA is an alteration in the conformation of the $N$-methyl substituted amide moiety. In the $N$-methylated PNA, the backbone carbonyl oxygens of the affected amide moieties are turned inward towards the nucleobases (Fig. 6) whereas the carbonyl oxygens are directed into solution in the structure of unmodified PNA. ${ }^{30}$ In the structure of the unmodified PNA hexamer specific water molecules that form a bridge between the backbone amide $\mathrm{NH}$ and the nucleobase were located for each base step. This hydrogen bonding donor has been eliminated in the modified PNA backbone. However, the water bridge is retained by coordination of the carbonyl oxygen and the water molecule, thereby leaving the $N$-methyl moiety exposed to the solvent. The water bridge between the backbone amide $\mathrm{NH}$ and the nucleobase is retained in the unmodified amide moieties of the $N$-methylated PNA, either through backbone amide $\mathrm{NH}$ or through the carbonyl oxygen, as two of these non-methylated amide moieties in each strand adopt two different conformations.

The backbone-nucleobase interactions through water molecules seem important for stabilizing the P-form helix of PNA. These interactions are still possible within the modified PNA backbone, and probably explain why no major overall structural difference is apparent between the PNA-PNA duplexes formed by $N$-methylated PNA as compared to normal PNA.

\section{Conclusion}

The present results demonstrate that PNA duplex (with DNA, RNA or PNA) and to a lesser extent (PNA) $)_{2}$-DNA triplex

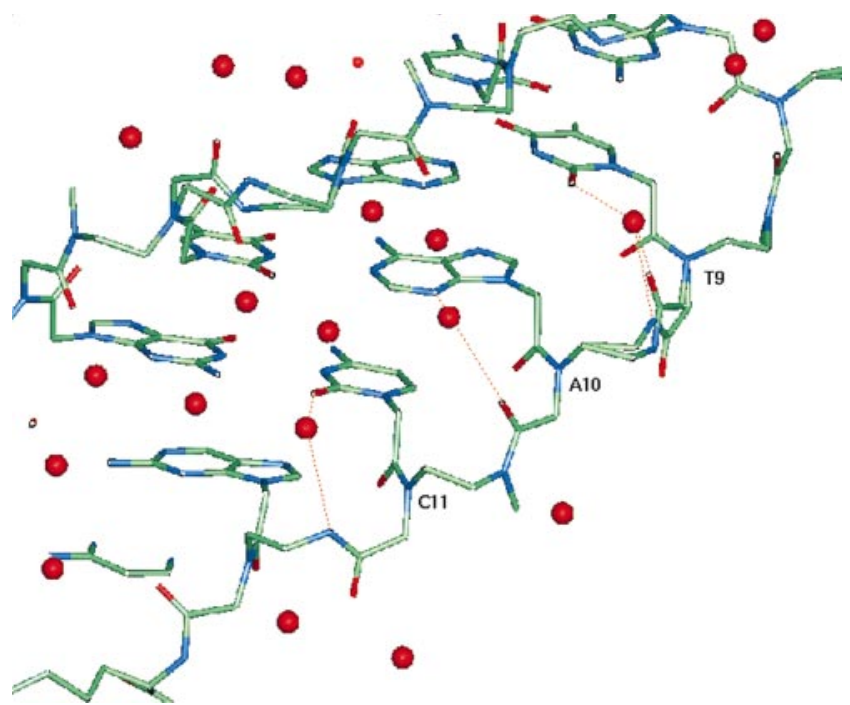

Fig. 6 Backbone (amide $\mathrm{NH}$ or $\mathrm{O}$ ) forms hydrogen bonds to water molecules, bridging the nucleobase and backbone in the double helical structure of the methylated PNA-PNA hexamer. Three representative base pairs are shown. PNA is colored by atom-types, and water molecules are depicted as red spheres. The figure was generated using the program $0 .{ }^{37}$ structures can without major loss in stability accommodate a limited number (at least $30 \%$ ) of $N$-methyl substitutions in the backbone. Most interestingly, duplexes and triplexes with fully methylated PNAs adopt helix conformations which judged by $\mathrm{CD}$ are distinctly different from the regular PNA structures. The crystal structure of the $50 \%$ modified PNA-PNA duplex shows that the $N$-methyl group is accommodated in the double helical structure by an alteration in the conformation of the affected amide moiety. This clearly indicates that $\mathrm{NH}$ hydrogen bonding is not crucial for stabilization of the structure as long as the possibility for formation of a nucleobasebackbone bridge through a water molecule is present. In conclusion these results indicate that $N$-alkylation can with only a moderate loss of hybridization potency be exploited as a means to modulate, for example the pharmacological properties of PNA.

\section{Acknowledgements}

The technical assistance of Annette Jørgensen and Brian Rosenberg is gratefully acknowledged. The work was supported by grants from The Danish National Research Foundation, PharmaBiotec and The Lundbeck Foundation.

\section{References}

1 E. Uhlmann and A. Peyman, Chem. Rev., 1990, 90, 544.

2 A. De Mesmaeker, K. H. Altmann, A. Waldner and S. Wendeborn, Curr. Opin. Struct. Biol., 1996, 5, 343.

3 M. Matteucci and R. W. Wagner, Science, 1996, 384, suppl. 20.

4 P. E. Nielsen, M. Egholm, R. H. Berg and O. Buchardt, Science, 1991, 254, 1497.

5 M. Egholm, O. Buchardt, P. E. Nielsen and R. H. Berg, J. Am. Chem. Soc., 1992, 114, 1895.

6 B. Hyrup and P. E. Nielsen, Bioorg. Biomed. Chem., 1996, 4, 53.

7 M. Eriksson and P. E. Nielsen, Quart. Rev. Biophysics, 1996, 29, 369.

8 H. Knudsen and P. E. Nielsen, Anti Cancer Drugs, 1996, 8, 113.

9 P. E. Nielsen and G. Haaima, Chem. Soc. Rev., 1997, 26, 73.

10 L. Good and P. E. Nielsen, Antisense Nucleic Acid Drug Dev., 1997, 7, 431

11 E. Uhlmann, A. Peyman, G. Breipohl and D. W. Will, Angew. Chem., Int. Ed., 1998, 37, 2796.

12 G. Haaima, A. Lohse, O. Buchardt and P. E. Nielsen, Angew. Chem., Int. Ed. Engl., 1996, 35, 1939.

13 A. Lenzi, G. Reginato and M. Taddei, Tetrahedron Lett., 1995, 36, 1713.

14 E. Lioy and H. Kessler, Liebig Ann., 1996, 201.

15 A. H. Krotz, O. Buchardt and P. E. Nielsen, Tetrahedron Lett., 1995, 36, 6937.

16 A. H. Krotz, O. Buchardt and P. E. Nielsen, Tetrahedron Lett., 1995, 36, 6941.

17 B. Hyrup, M. Egholm, O. Buchardt and P. E. Nielsen, Bioorg. Med. Chem. Lett., 1996, 6, 1083.

18 P. Lagriffoule, O. Buchardt, P. Wittung, B. Nordén, K. K. Jensen and P. E. Nielsen, Chem. Eur. J., 1997, 3, 912. 
19 S. Jordan, C. Schwemler, W. Kosch, A. Kretschmer, U. Stropp, E. Schwenner and B. Mielke, Bioorg. Med. Chem. Lett., 1997, 7, 687.

20 A. Peyman, E. Uhlmann, K. Wagner, S. Augustin, G. Breipohl, D. W. Will, A. Schäfer and H. Wallmeier, Angew. Chem., Int. Ed. Engl., 1996, 35, 2636.

21 N. M. Howarth and L. P. G. Wakelin, J. Org. Chem., 1997, 62, 5441.

22 C. Garcia-Escheverria, D. Hüsken, C. S. Chiesi and K.-H. Altmann, Bioorg. Med. Chem. Lett., 1997, 7, 1123.

23 V. S. Rana, V. A. Kumar and K. N. Ganesh, Bioorg. Med. Chem. Lett., 1997, 7, 2837.

24 V. A. Efimov, M. V. Choob, A. A. Buryakova, A. L. Kalinkina and O. G. Chakhmakhcheva, Nucleic Acids Res., 1998, 26, 566.

25 Ö. Almarsson, T. C. Bruice, J. Kerr and R. N. Zuckermann, Proc. Natl. Acad. Sci. USA, 1993, 90, 7518.

26 Ö. Almarsson and T. C. Bruice, Proc. Natl. Acad. Sci. USA, 1993, 90, 9542.

27 S. C. Brown, S. A. Thomson, J. M. Veal and D. G. Davis, Science, 1994, 265, 777.

28 M. Eriksson and P. E. Nielsen, Natur. Struct. Biol., 1996, 3, 410

29 L. Betts, J. A. Josey, J. M. Veal and S. R. Jordan, Science, 1995, 270, 1838.

30 H. Rasmussen, J. S. Kastrup, J. N. Nielsen, J. M. Nielsen and P. E. Nielsen, Natur. Struct. Biol., 1996, $2,98$.
31 L. Christensen, R. Fitzpatrick, B. Gildea, K. H. Petersen, H. F. Hansen, T. Koch, M. Egholm, O. Buchardt, P. E. Nielsen, J. Coull and R. H. Berg, J. Pept. Sci., 1995, 3, 175

32 J. Jancarik and S.-H. Kim, J. Appl. Crystallogr., 1991, 24, 409.

33 Z. Otwinowski, in Proceedings of the CCP4 Study Weekend: Data Collection and Processing, ed. L. Sawyer, N. Isaacs and S. S. Bailey, SERC Daresbury Laboratory, Warrington, 1993, pp. 5662.

34 Collaborative Computational Project, Number 4, Acta Crystallogr., Sect. D, 1994, 50, 760.

35 J. Navaza, Acta Crystallogr., 1994, 50, 157

36 T. A. Brünger, J. Kuriyan and M. Karplus, Science, 1987, 235, 458.

37 T. A. Jones, J.-Y. Zou, S. W. Cowan and M. Kjeldgaard, Acta Crystallogr., Sect. A, 1991, 47, 110.

38 K. L. Dueholm, M. Egholm, C. Behrens, L. Christensen, H. F. Hansen, T. Vulpius, K. Petersen, R. H. Berg, P. E. Nielsen and O. Buchardt, J. Org. Chem., 1994, 59, 5767.

39 K. L. Dueholm and P. E. Nielsen, New J. Chem., 1997, 21, 19.

40 M. Egholm, L. Christensen, K. L. Dueholm, O. Buchardt, J. Coull and P. E. Nielsen, Nucleic Acids Res., 1995, 23, 217.

41 R. Lavery and H. J. Sklenar, J. Biomol. Struct. Dyn., 1998, 6, 63.

Paper 9/02091H 